Legal shadow over laser patent

First court

verdict for Gould claims

\section{Washington}

The simmering debate over who should be credited with the invention of the laser entered a new phase last week when a federal judge in San Francisco, spurred on by a New York technology investment company, upheld a patent issued to physicist Dr Gordon Gould as taking precedence over the original patent issued to Dr Charles Townes and Dr Arthur Schawlow in 1960.

Dr Townes shared the Nobel prize, with two Soviet physicists, in 1964 for his work in quantum electronics and microwave spectroscopy leading to the development of the laser or Light Amplification by Stimulated Emission of Radiation. Dr Schawlow shared the Nobel prize for his work as a chemist in the same area last year. Both are generally credited with putting forward the first conceptual design for a laser in a scientific paper published in Physical Review in December 1958 (112, 1940; 1958).

Dr Gould, however, who worked a few doors away from Dr Townes's laboratory at Columbia University in New York in 1957, claims that a notebook kept at the time demonstrates that he was the one to coin the word laser. He also claims that his conception, as described by his investment company backer, was that of an amplifying device, and should thus entitle him to credit for the conception of the laser as a whole.

It could not be established on Monday whether Dr Gould's claim extends to the basic process by which photons are amplified within a laser or to some other feature of the device. The substance of the claim appears to be the notion of creating a population of excited atoms, capable of stimulated emission, by exposing a gas or other material to an intense flash of light.

Dr Gould's claims for patent rights extending to an estimated $25-35$ per cent of all lasers on the market, have been vigorously pursued by a New York-based company Refac Technology Development. With another company, Patlex of Pennsylvania, Refac has bought 80 per cent of any royalties generated by Dr Gould's patent for a sum claimed to be over $\$ 2$ million, and says it is now defending his claims to the laser against those of the scientific and technical establishment.

Until last week, the courts had been relatively unsympathetic. Dr Gould has failed several times to have revoked the patent granted to Townes and Schawlow in 1960, when both were working at Bell Laboratories, on the grounds that he had

been the first to conceive a complete working laser.

In 1977, however, the US Patent Office awarded Dr Gould a patent on his claim to have designed the amplifying device referred to in the patent. Since then, Refac has sought to obtain royalties from all companies producing optically-pumped lasers, and says that on the basis of a 1979 patent, also granted to Gould, it will now seek royalties on the use of such lasers.

Last week's decision, the first time that the validity of the patent has been tested in a federal court, was based on a suit filed by Refac against the Palo Alto-based company General Photonics claiming infringement of Gould's patent rights and demanding royalties on all lasers produced by the company since 1977 .

Refac claims that Dr Gould should have received the technical - if not the scientific - credit for the first laser. The arguments

\title{
UN university goes on tour
}

\section{Paris, February}

Global modellers, the inheritors of those who gave us The Limits to Growth in 1972, gathered here from 22 to 25 February to advise the Tokyo-based United Nations University on its preoccupation with the problems of agriculture, energy and development. The symposium, organized by Professor Maurice Lévy of the Marie and Pierre Curie University (otherwise Paris VI), seems not finally to have persuaded the university to take global modelling to its bosom, but the rector, the Indonesian Soedjatmako, and his four vice-rectors undertook to brood about the problem when they are back in Tokyo.

Part of the interest of the occasion was that it showed how stimulating modelling techniques of socio-economic problems have proved to be, if only as a spur to understanding how one variable is related to another. Thus a model of the rural economy of Bangladesh was widely acclaimed, but the work of the International Institute for Applied Systems Analysis, of the Organization for Economic Cooperation and Development and of Dr Sam Cole (University of Sussex) also received high marks.

Professor Donella Meadows, who has been working on a model of the rural economy of New England since her collaboration on the original Club of Rome report, argued passionately at the symposium for a kind of global network of global modellers, linked together by communications satellites and thus able to exchange information or computational codes easily. The United Nations University cautiously with held its blessing.

One of the problems of such occasions is that the participants are in two camps - convinced Judge Samuel Conti and, as a result of his ruling in favour of Refac, General Photonics has agreed to pay the company 8 per cent of all its future sales.

Dr Arthur Schawlow, now professor of physics at Stanford University, has said that the US Patent Office was wrong to issue Dr Gould with the 1977 patent, and that Dr Townes "may have told Gould what he was doing" during conversations at Columbia in 1958. Dr Shawlow also says that drafts of the subsequent Physical Review paper were already circulating in the laboratory in August 1958, the date on which Gould wrote down some of his ideas.

$\mathrm{Mr}$ E.M. Lang, president of Refac, argues conversely that Gould spoke to Townes about his ideas on how to produce an amplifier that would make the laser work, and that it was Gould's ideas which were later incorporated into early laser designs for which Townes and Schawlow

those who would construct models that address some tangible aspect of a problem and those who hold that complexity is of the essence. Some of the most confusing (and energetic) contributions to the discussion came from those who argued that "techno-economic" models purporting to account for, say, the effects of fuel prices on food production, were certain to be inadequate, given their neglect of "socio-political" considerations.

The interest of the United Nations University in these studies stems from its wish partially to focus its interest on the encouragement of economic development on what the symposium called "the energyagriculture nexus". Inevitably, in a gathering of systems analysts, some argued that "food" would be a better variable than "agriculture".

The United Nations University is not so much a university as the late U Thant's creation of a United Nations development agency. Its chief source of funds is a pledge of $\$ 100$ million from the government of Japan. The university has no students, while all its employees are on short-term contracts. According to Soedjatmako, negotiations are now under way for a permanent building in Tokyo, although this is unlikely to be built before the end of his term of office in 1985 .

Lacking a permanent establishment, the university works chiefly by forming links with academic groups elsewhere, in industrialized and developing countries alike. It was encouraged, at the end of its four-day stand in Paris last month, to be told by the newly created minister of external affairs at the French Department of Education that French academics will be asked to collaborate with the university. 